\author{
https://doi.org/10.34142/23129387.2019.61.02 \\ UDC 159.922:376.011.3-051 \\ ORCID 0000-0001-8292-1791
}

\title{
INVESTIGATING PROFESSIONAL AWARENESS OF THE CORRECTIONAL PEDAGOGUE Maryna Omelchenko,
}

Associate Professor of Special Pedagogy and Inclusion

\author{
Department,
}

SHEI «Donbas State Pedagogical University», Ukraine

E-mail:neckaa87@gmail.com

Aim: The paper is devoted to highlighting the results of investigating the peculiarities of professional awareness of correctional pedagogues.

Research methods: To achieve the goals of the investigation, business games, testing, evaluation of correctional pedagogues by the supervisor (curator, director), analysis of special documentation, activity monitoring and the method of solving professional tasks have been used. The results have been processed mathematically and accumulated in the database. They have been developed and represented in the form of tables.

To determine the levels of development of professional awareness of correctional pedagogues both theoretical and empirical approaches have been used.

Results: In the paper the detailed description of the developed levels of each component of professional awareness (cognitive, reflexive, axiological, motivational, affective) is presented, the main stages of the investigation work are determined: structuring of professional awareness; external evaluation of the correctional pedagogue's activity; comparative analysis of the results of the investigation of the first and second stages of the experiment; dependencies between levels of professional awareness and different factors of professional activity development are established. The numerical results obtained during the experiment are also given. The factors of influence on the levels of development of professional awareness of correctional pedagogues are revealed: experience professional activity, working conditions, personal circumstances, awareness of issues of 
importance of the level of professional awareness and its components in the professional development of the employee. The results obtained during the investigation have provided the bases for developing the ways to optimize the forming professional awareness of correctional pedagogues: expanding the experience of professional activity; creating optimal professional conditions; adapting personal circumstances; disseminating the knowledge on issues of importance of level of professional awareness and its components in professional development of correctional pedagogues.

Conclusions: The materials covered in the paper indicate the need: to increase the levels of development of the professional awareness of correctional pedagogues; to form the adequate professional self-esteem; to establish the dependency between professional awareness and the level of professional competence; to ensure positive impact of identified factors of professional awareness development; to form the developing technology for optimization of the process of professional awareness development in correctional pedagogues with different work experience.

Keywords: correctional educator; professional activity; professional self-esteem; professional consciousness; professional development.

\section{Дослідження професійної свідомості корекційного педагога \\ Марина С. Омельченко,}

кандидат педагогічних наук, доцент кафедри спеціальної педагогіки та інклюзї,

ДВНЗ «Донбаський державний педагогічний університет», м. Слов'янськ, Донеиька обл., Украӥна

Мета: стаття присвячена висвітленню результатів дослідження особливостей професійної свідомості корекиійних педагогів.

Методи: Для досягнення иілей дослідження було використано ділові ігри, тестування, оцінювання корекиійного педагога керівником (куратором, директором), аналіз спеціальної документаиії, спостереження за діяльністю та метод розв'язання професійних задач. Результати обробляються математично і накопичуються $в$ базі даних. Вони розроблені і представлені у форматі таблиць. 
Результати: Для визначення рівнів розвитку професійної свідомості корекційних педагогів застосовувалися як теоретичні, так $i$ емпіричні підходи. У статті представлено детальний опис розроблених рівнів за кожною компонентою професійної свідомості (когнітивною, рефлексійною, аксіологічною, мотиваційною, афективною), визначено основні етапи дослідницької роботи: структурування професійної свідомості; зовнішне оцінювання діяльності корекиійного педагога; порівняльний аналіз результатів дослідження першого та другого етапів експерименту; встановлено залежності між рівнями професійної свідомості й різними факторами розвитку професійної діяльності. Також наводяться отримані в ході експерименту числові результати. Виявлено фактори впливу на рівні розвитку професійної свідомості корекційних педагогів: досвід професійної діяльності, умови пращі, особистісні обставини, обізнаність у питаннях значущості рівня професійної свідомості та ї̈ компонент у професійному розвитку працівника. Отримані в ході дослідження результати дали підстави для розроблення шляхів оптимізації розвитку професійної свідомості корекційних педагогів: поширення досвіду професійної діяльності; створення оптимальних професійних умов; адаптування особистісних обставин; поширення знань щодо питань значущості рівня професійної свідомості та ї̈ компонент у професійному розвитку корекиійного педагога.

Висновки: Висвітлені у статті матеріали дозволяють зазначити необхідність: підвищення рівнів розвитку професійної свідомості корекційних педагогів; формування адекватної професійної самооиінки; встановлення залежності між професійною свідомістю та рівнем професійної компетентності; забезпечення позитивного впливу виявлених факторів розвитку професійної свідомості; розроблення розвиткової технології щзодо оптимізації процесу розвитку професійної свідомості у корекційних педагогів з різним досвідом роботи.

Ключові слова: корекційний педагог; професійна діяльність; професійна самооиінка; професійна свідомість; професійний розвиток. 
Introduction. Creating the New Ukrainian School, performing the reforms in the Ukrainian educational sector and implementing the ideas on introducing the inclusive forms of training for persons with mental and physical disorders favor the functional duties of the pedagogical staff and, consequently, increasing the professional requirements for them. Such changes entail not only the increase in the list of educational services but also require the expansion in their quality, which primarily depends on the professional characteristics of pedagogues.

The correctional pedagogue is a key figure in the system of education and upbringing of the child with disorders of psychophysical development. His/her professional activities consist of carrying out advisory, diagnostic, social-pedagogical, rehabilitation, psychotherapeutic, corrective-developmental and other interdependent professional functions.

To perform successfully all the professional tasks, the correctional pedagogue must be prepared for their being implemented psychologically, physically, intellectually, morally, and, what is the most important, professionally. At the same time, the core factor is the personality of the correctional pedagogue who determines the essence of his/her professional activities: for the sake of which he/she works, which goals and tasks he/she sets, which means and techniques he/she chooses. In this context, the pedagogue's professional and pedagogical position plays an important role - his/her worldview, attitude towards his/her professional duties, professional behavior; his/her system of intellectual, volitional and emotional-appraisal attitudes toward the world and actually his/her pedagogical activities (Slobodchikov, 2013).

Combining in its essence such psychic constituents as professional the Self-concept, professional reflection, and professional self-esteem, the professional-pedagogical position is one of the important manifestations of the professional awareness, 
forming and developing which is directly related to the general professional formation and development of the personality of the pedagogue.

Aim. The purpose of the paper is to study the level of development of the components of the professional awareness of correctional pedagogues at different stages of their professionalization.

The objectives of the paper are to consider the structure of the professional awareness; the determine the stages of studying the components of the professional awareness of the correctional pedagogue; to analyze the results of studying the professional awareness of the correctional pedagogue at different stages of professionalization.

Methodology of Research. The levels of the development of professional awareness have been determined in accordance with the indicators allocated at the stage of stating. These indicators have become the identifiers of the formation of the professional awareness of the correctional pedagogues.

The following methods have been used: business games, testing, evaluation of the correctional pedagogues by the administrator (supervising professor, director), analysis of the special documentation, monitoring the activities and solving professional tasks. The study has been conducted in the groups of the magistracy of pedagogical universities, in the pedagogical staffs of special preschool institutions and inclusive groups of preschool institutions, inclusive classes, as well as special secondary comprehensive schools.

The method of conducting business games is aimed at identifying the level of awareness of the correctional pedagogues in the problems of understanding the essence, the main components and the role of professional awareness in the development of the professional activities; at actualizing the problem of own professional awareness in the correctional pedagogues. Those under 
study independently have practiced in allocating the main components of the professional awareness, on this occasion they have prepared reports, discussed, summed up together.

The testing method consists of the five questionnaires which purpose is to identify the formation of the main components of the professional awareness of the correctional pedagogues. The questionnaires contain from 14 to 50 statements; the correct answer should be chosen to each of them.

The method of evaluating the correctional pedagogue in the course of the conversation with the administrator (supervising professor, head, director) becomes a prerequisite for determining the level of his/her professional awareness. It is the leaders of educational institutions who are aware of the needs and feelings of the members of the pedagogical staff best of all, they can carry out objective control and assessment of their employees' work, understand the inner world, know the personal qualities and professional capabilities of their employees.

The method of analysis of the special documentation of the correctional pedagogue provides is supposed to study the job descriptions carefully, working plans, working books of interaction with other specialists of the institution and parents of children, consultation journals, printed works, analysis of annual activities. In the essence of the above-defined documents, the manifestations of indicators of the components of the professional awareness of the correctional pedagogues are determined.

The method of monitoring the activity of the correctional pedagogue and solving his/her assigned professional tasks is realized through direct consideration of the professional activities of the correctional pedagogues, conversations, and the participation of pedagogues in the simulated professional situations that are aimed at identifying the indicators of the components of the professional awareness. 


\subsection{Level of Development of Professional Awareness of Correctional Pedagogue}

On the basis of the content analysis of the determined indicators, the characteristics of the levels of formation of the components of the professional awareness of the correctional pedagogues have been compiled, which are evaluated according to the four-level system:

Table 1.

\section{Levels of Development of Professional Awareness of Correctional Pedagogues}

\begin{tabular}{|c|c|}
\hline \multicolumn{2}{|r|}{ Insufficient level } \\
\hline $\begin{array}{l}\text { Component } \\
\text { of professional } \\
\text { awareness } \\
\end{array}$ & Indicators of components \\
\hline $\begin{array}{l}\text { Professional- } \\
\text { gnosiological }\end{array}$ & $\begin{array}{l}\text { Theoretical knowledge of correctional pedagogues is } \\
\text { undifferentiated, limited by the basic theoretical foundations of } \\
\text { special pedagogy and psychology, often used spontaneously and } \\
\text { detached from the reality of the practice of working with the } \\
\text { children with disorders of psychophysical development. In the } \\
\text { course of vocational education, such pedagogues did not show } \\
\text { significant interest in learning, did not show high results, as a } \\
\text { rule, were not interested in conferences, contests, symposia. } \\
\text { Knowledge of own professional predestination and } \\
\text { professional duties is also incomplete, limited, often that does } \\
\text { not meet the requirements of modern educational institutions. }\end{array}$ \\
\hline $\begin{array}{l}\text { Professional- } \\
\text { reflexive }\end{array}$ & $\begin{array}{l}\text { There are significant differences between the "Self"-ideal } \\
\text { and the "Self"-real. At the same time the defining indicators are } \\
\text { the unawareness of own affiliation with the professional } \\
\text { community; inadequate professional self-esteem; inflated or, } \\
\text { conversely, too low level of professional harassment; } \\
\text { dissatisfaction with the chosen profession, inability to rationally } \\
\text { design his/her own professional path or to plan professional } \\
\text { activities; lack of professional ideals and anti-ideals. } \\
\text { Correctional pedagogues with insufficient professional } \\
\text { awareness have not realized themselves in the profession. }\end{array}$ \\
\hline $\begin{array}{c}\text { Professional- } \\
\text { axiological }\end{array}$ & $\begin{array}{l}\text { All the groups of professional values (social, group, } \\
\text { individual) are unformed. Correctional pedagogues with an } \\
\text { insufficient level of professional awareness do not understand }\end{array}$ \\
\hline
\end{tabular}




\begin{tabular}{|c|c|}
\hline & $\begin{array}{l}\text { the social value of their profession, or they understand it one- } \\
\text { sidedly. Such pedagogues find it hard to work in a team, they } \\
\text { often violate regulations and rules of team work, that is why } \\
\text { constantly there appear professional difficulties. The personal } \\
\text { system of their professional values is oriented on the priority of } \\
\text { material goods, evasion from the performance of professional } \\
\text { duties, the possibility of obtaining personal gain. }\end{array}$ \\
\hline $\begin{array}{l}\text { Professional- } \\
\text { motivational }\end{array}$ & $\begin{array}{l}\text { The goals and motives of the professional activities of } \\
\text { correctional pedagogues reflect mainly his/her personal interests } \\
\text { related to his/her own needs (money, food, clothes, family } \\
\text { retention, etc.). Such pedagogues are always looking for a } \\
\text { benefit in their profession, trying to avoid over-the-counter labor, } \\
\text { focusing not on the quality and efficiency of their own } \\
\text { professional activities, but mainly on the amount of time spent, } \\
\text { the amount of money earned, and the comfort of working } \\
\text { conditions. Correctional pedagogues with the unsatisfactory level } \\
\text { of professional awareness can be aspired to get a higher position, } \\
\text { and thus increasing their social status, being recognized by } \\
\text { others, gaining more powers. }\end{array}$ \\
\hline $\begin{array}{l}\text { Professional- } \\
\text { emotional }\end{array}$ & $\begin{array}{l}\text { Correctional pedagogues rarely feel positive emotions from } \\
\text { professional activities (satisfaction with work, professional pride, } \\
\text { joy from the pursuit of professional goals). He/she more than } \\
\text { others is subject to stress, more often experiences professional } \\
\text { burnout, which in the end leads to negative consequences not } \\
\text { only in professional activities but also in personal states. }\end{array}$ \\
\hline \multicolumn{2}{|r|}{ Initial level } \\
\hline $\begin{array}{l}\text { Component } \\
\text { of professional } \\
\text { awareness }\end{array}$ & Indicators of components \\
\hline $\begin{array}{l}\text { Professional- } \\
\text { gnosiological }\end{array}$ & $\begin{array}{l}\text { Professional knowledge and representations of the } \\
\text { correctional pedagogues with the initial level of the professional } \\
\text { awareness constitute a system that includes theoretical } \\
\text { information from the branches of the pedagogical, psychological } \\
\text { and medical sciences, which the pedagogues combine to some } \\
\text { extent with the practical experience of their professional } \\
\text { activities. This category of pedagogues is practically not engaged } \\
\text { in research activities, does not apply a creative approach in the } \\
\text { course of solving professional problems, because of which using } \\
\text { the available knowledge and representations is mostly } \\
\text { reproductive in nature. Due to the lack of some theoretical }\end{array}$ \\
\hline
\end{tabular}




\begin{tabular}{|c|c|}
\hline & $\begin{array}{l}\text { foundation, professional knowledge and ideas of the correctional } \\
\text { pedagogues can often be incomplete, erroneous, fragmentary, } \\
\text { tied to specific content, which in its turn affects the quality of } \\
\text { his/her practical professional activities. }\end{array}$ \\
\hline $\begin{array}{l}\text { Professional- } \\
\text { reflexive }\end{array}$ & $\begin{array}{l}\text { The correctional pedagogue has fairly clear correct ideas } \\
\text { about the requirements for his/her own professional activities } \\
\text { (the "Self"-perfect), while the "Self"-real often does not coincide } \\
\text { with the expected result. Such a pedagogue cannot to some } \\
\text { extent understand his/her own "strong" sides and, at the same } \\
\text { time, minimize the "weak" ones. Because of this, the choices } \\
\text { made to achieve professional goals are often ineffective. At the } \\
\text { initial level of professional awareness, the correctional } \\
\text { pedagogue is difficult to differentiate professional abilities, due } \\
\text { to which there are difficulties in his/her development. All the } \\
\text { outlined problems of the professional-reflexive sphere of this } \\
\text { category of pedagogues significantly impede the process of their } \\
\text { professional self-realization. }\end{array}$ \\
\hline $\begin{array}{l}\text { Professional- } \\
\text { axiological }\end{array}$ & $\begin{array}{l}\text { The correctional pedagogues with the initial level of } \\
\text { professional awareness have a formed system of the professional } \\
\text { society and value orientations. They understand the value of the } \\
\text { chosen profession but often within the limits of satisfaction of } \\
\text { material needs, while labor never occupies a priority position. } \\
\text { The peculiarity of the pedagogues with the initial level of the } \\
\text { professional awareness is that they value more than what is } \\
\text { usually lacking: social status, well-being, social relationships, to } \\
\text { a lesser extent that one which is connected with spiritual growth, } \\
\text { personal and professional development. }\end{array}$ \\
\hline $\begin{array}{l}\text { Professional- } \\
\text { motivational }\end{array}$ & $\begin{array}{l}\text { Along with the goals and motives aimed at obtaining } \\
\text { material benefits and ensuring stable and comfortable conditions } \\
\text { for the professional environment, a significant role for the } \\
\text { correctional pedagogues with the initial level of the professional } \\
\text { awareness is played by the need for social contacts, establishing } \\
\text { stable and long-term relationships with colleagues, gaining } \\
\text { professional recognition from others. Such pedagogues, as a rule, } \\
\text { establish friendly relations with both children and their parents, } \\
\text { are easily adapted to the pedagogical staff. It has been observed } \\
\text { that the effectiveness of the work of this category of the } \\
\text { pedagogues has been greatly influenced by the fact to which } \\
\text { extent their actions are approved and appreciated by the } \\
\text { surroundings. Professional goals which are chosen by the }\end{array}$ \\
\hline
\end{tabular}




\begin{tabular}{|c|c|}
\hline & $\begin{array}{l}\text { pedagogue with the initial level of the professional awareness in } \\
\text { his/her activities, in most cases, are due to the degree of approval } \\
\text { from other subjects. }\end{array}$ \\
\hline $\begin{array}{c}\text { Professional- } \\
\text { emotional }\end{array}$ & $\begin{array}{l}\text { The correctional pedagogue experiences significant } \\
\text { difficulties in managing his/her own professional feelings and } \\
\text { emotions both negative (fear, insecurity, frustration, irritability) } \\
\text { and positive (joy, passion, happiness) ones. Failures, fatigue, } \\
\text { changes in the environment and other events of his/her } \\
\text { professional life quickly deduce such a pedagogue out of the } \\
\text { state of emotional equilibrium. The correctional pedagogue with } \\
\text { the initial level of the professional awareness is more likely to be } \\
\text { subject to emotional stress, it is difficult for him/her to determine } \\
\text { his/her emotional state in the right way, correct it. The quality of } \\
\text { professional emotions and feelings of this category of } \\
\text { pedagogues is marked by volatility and instability. }\end{array}$ \\
\hline \multicolumn{2}{|r|}{ Sufficient level } \\
\hline $\begin{array}{l}\text { Component } \\
\text { of professional } \\
\text { awareness }\end{array}$ & Indicators of \\
\hline $\begin{array}{l}\text { Professional- } \\
\text { gnosiological }\end{array}$ & $\begin{array}{l}\text { The correctional pedagogue with the sufficient level of } \\
\text { professional awareness has a system of profound and } \\
\text { substantiated professional knowledge and ideas that he/she uses } \\
\text { skillfully in his/her own professional activities. Such a } \\
\text { pedagogue is actively interested in scientific investigations, } \\
\text { events and news in the field of his/her profession, with pleasure, } \\
\text { expands his/her professional outlook, accumulates knowledge, } \\
\text { with pleasure sharing his/her own experience. The correctional } \\
\text { pedagogue is an active participant in conferences and seminars } \\
\text { and is often their organizer. } \\
\text { In the practical activities, the specialist shows a high result, } \\
\text { because all his/her decisions and actions are based on solid } \\
\text { professional knowledge and ideas, backed up by the successful } \\
\text { practice of the professional activities. }\end{array}$ \\
\hline $\begin{array}{l}\text { Professional- } \\
\text { reflexive }\end{array}$ & $\begin{array}{l}\text { The correctional pedagogue is well aware of the } \\
\text { requirements and conditions necessary for the successful } \\
\text { resolution of his/her professional tasks, makes efforts to } \\
\text { maximally approximate the "Self"-real to the "Self"-ideal in the } \\
\text { profession. He/She sets reasonable goals in his/her professional } \\
\text { activities, adequately assesses his/her own capabilities, } \\
\text { circumstances, prospects, on the basis of which, as a rule, makes }\end{array}$ \\
\hline
\end{tabular}




\begin{tabular}{|c|c|}
\hline & $\begin{array}{l}\text { the right solutions. } \\
\text { At the sufficient level of development of the professional } \\
\text { awareness, the correctional pedagogue not only correctly } \\
\text { assesses his/her professional disadvantages and advantages, but } \\
\text { can consciously influence them, minimizing the negative, and, } \\
\text { conversely, developing positive ones. All this becomes a } \\
\text { powerful factor for the successful professional self-realization of } \\
\text { the pedagogue. }\end{array}$ \\
\hline $\begin{array}{l}\text { Professional- } \\
\text { axiological }\end{array}$ & $\begin{array}{l}\text { The priority positions in the system of professional values of } \\
\text { the correctional pedagogues with the sufficient level of } \\
\text { development of the professional awareness take positive results } \\
\text { of work, spiritual and personal growth, and their own } \\
\text { professional development. Their social ties and status, their } \\
\text { financial situation of such pedagogues do not come to the } \\
\text { background but manifest themselves to a lesser extent than with } \\
\text { the insufficient and initial levels of development of professional } \\
\text { awareness. }\end{array}$ \\
\hline $\begin{array}{l}\text { Professional- } \\
\text { motivational }\end{array}$ & $\begin{array}{l}\text { The priority motives for the professional activities of the } \\
\text { correctional pedagogue is to achieve certain professional goals, a } \\
\text { sense of his/her own professional ability. For such pedagogues, } \\
\text { the problem of material rewards, the need for comfortable living } \\
\text { conditions, social ties are not the basic ones. } \\
\text { The correctional pedagogues with the sufficient level of the } \\
\text { professional awareness dislike routine, strict rules and directions. } \\
\text { They strive for change and creativity. The pedagogue is open to } \\
\text { new ideas, he/she likes to solve complex professional problems, } \\
\text { to think, they are driven by the desire for achievement and } \\
\text { success. }\end{array}$ \\
\hline $\begin{array}{c}\text { Professional- } \\
\text { emotional }\end{array}$ & $\begin{array}{l}\text { Professional emotions and feelings of the correctional } \\
\text { pedagogue with the sufficient level of the professional awareness } \\
\text { are based on a deep knowledge of the essence of his/her own } \\
\text { profession, adequate professional-reflexive activities, a stable } \\
\text { professional-value system. Such pedagogues are able to manage } \\
\text { their emotional manifestations, to maintain balance, and to } \\
\text { prevent emotional stress, eliminate them. } \\
\text { His/her own professional activity causes the correctional } \\
\text { pedagogue to a greater extent such emotions and feelings as } \\
\text { interest, curiosity, anxiety, anticipation, assimilation, ardor, } \\
\text { enthusiasm. }\end{array}$ \\
\hline
\end{tabular}




\begin{tabular}{|c|c|}
\hline \multicolumn{2}{|r|}{ High level } \\
\hline $\begin{array}{l}\text { Component } \\
\text { of professional } \\
\text { awareness }\end{array}$ & Indicators of components \\
\hline $\begin{array}{l}\text { Professional- } \\
\text { gnosiological }\end{array}$ & $\begin{array}{l}\text { The correctional pedagogue with the high level of } \\
\text { professional awareness has deep knowledge and ideas that can } \\
\text { be successfully applied in his/her practical professional } \\
\text { activities. When working, such a pedagogue is successful and } \\
\text { has high results, avoids excessive mental fatigue due to the } \\
\text { ability to use rational ways and techniques for solving } \\
\text { professional problems. } \\
\text { Such a pedagogue takes an active part in scientific projects, } \\
\text { is an active participant in scientific studies, is usually engaged in } \\
\text { various inventions and experiments with pleasure. Execution of } \\
\text { professional tasks of the correctional pedagogue with the high } \\
\text { level of professional awareness is marked by high quality and } \\
\text { skills. }\end{array}$ \\
\hline $\begin{array}{l}\text { Professional- } \\
\text { reflexive }\end{array}$ & $\begin{array}{l}\text { The correctional pedagogue with the high level of the } \\
\text { professional awareness is able to take an active research position } \\
\text { in relation to his/her own professional activities, to carry out } \\
\text { his/her critical analysis, and to evaluate the effectiveness of } \\
\text { his/her results adequately. The pedagogue is able to clearly } \\
\text { outline the situation and circumstances, bring them to the level } \\
\text { of analysis and transformation, to make the right decision in } \\
\text { time. The correctional pedagogue adequately assesses his/her } \\
\text { own professional position, realizes the difficulties, is constantly } \\
\text { looking for ways to overcome them. } \\
\text { The pedagogue with the high level of professional } \\
\text { awareness, as a rule, possesses a psychological mechanism of } \\
\text { professional self-improvement and self-actualization, tends to } \\
\text { take an analytical position regarding his/her own professional } \\
\text { activities. The correctional pedagogue is also able to generalize } \\
\text { his/her professional experience, to define his/her own criteria } \\
\text { that will determine the effectiveness and success of the } \\
\text { professional activities in terms of subjectivity. Thus, the } \\
\text { professional activities for such a pedagogue are the object of } \\
\text { studying and designing, becomes flexible and conscious, } \\
\text { oriented to overcoming problems and achieving professional } \\
\text { goals. }\end{array}$ \\
\hline Professional- & At the head of the professional-value system of the \\
\hline
\end{tabular}




\begin{tabular}{|c|c|}
\hline axiological & $\begin{array}{l}\text { correctional pedagogue, there are values associated with } \\
\text { productive professional self-realization and satisfaction with it, } \\
\text { which is based on its own criteria for this self-realization. } \\
\text { All other values related to satisfying the various needs of the } \\
\text { pedagogue (material, social, spiritual) operate and function in a } \\
\text { variety of ways, which are made up of the professional activities } \\
\text { and beyond. }\end{array}$ \\
\hline $\begin{array}{l}\text { Professional- } \\
\text { motivational }\end{array}$ & $\begin{array}{l}\text { The main motives of the professional activities of the } \\
\text { correctional pedagogue are the need for creativity (the need for } \\
\text { space where the pedagogue could realize his/her ideas, to show } \\
\text { talents); the need for self-improvement and development } \\
\text { (manifested as a desire for independence, self-determination, } \\
\text { self-improvement); the need for interesting work, which is of a } \\
\text { special meaning and essence (the need for a sense of demand, } \\
\text { performance of socially useful work). } \\
\text { The most important for the correctional pedagogues with the } \\
\text { high level of professional awareness is the allocation of time and } \\
\text { resources that would allow to sharpen professional skills, } \\
\text { improve competence, increase productivity. }\end{array}$ \\
\hline $\begin{array}{c}\text { Professional- } \\
\text { emotional }\end{array}$ & $\begin{array}{l}\text { The stability of the emotions and feelings of the correctional } \\
\text { pedagogue, the high skill in managing and controlling them, } \\
\text { follow the high indicators of other components of the high level } \\
\text { of professional awareness. } \\
\text { Professional stresses do not have devastating consequences } \\
\text { for such a pedagogue, because he/she is well aware of his/her } \\
\text { emotional state and his/her prospects, can affect it and change it. } \\
\text { The professional activities of this category of the } \\
\text { correctional pedagogues are mostly presented by positive } \\
\text { emotions and feelings, among which in the foreground there are } \\
\text { desire, inspiration, excitement, interest, joy, calmness, pleasure, } \\
\text { enthusiasm. }\end{array}$ \\
\hline
\end{tabular}

The professional awareness of the correctional pedagogue is considered a system of beliefs, ideas, attitudes and other personality characteristics of an individual, which in many people determine not only his/her professional actions, but also the course of formation of the professional activities in general. 
As it has been mentioned above, the awareness of the correctional pedagogue is considered from two positions: general and special. Accordingly, it has been identified two blocks of awareness: general and special (professional).

The general block of awareness of the correctional pedagogue includes the components commonly accepted for awareness (epistemological, reflexive, axiological, emotional-volitional, and motivational). The special block of awareness consists of components determined for studying the structure and mechanism of forming such an integral foundation of the personality of the correctional pedagogue as a professional awareness.

Results. 1.1. Experimental Studying the Professional Awareness of the Correctional Pedagogue. Studying the professional awareness of the correctional pedagogues has been conducted with the help of the experiment which has last for an academic year with undergraduates of higher educational institutions, educators and teachers- speech pathologists of special preschool institutions and inclusive groups, assistants of inclusive classes as well as with the teachers of special secondary comprehensive schools of Donetsk, Kharkiv, Odesa regions of Ukraine. In the experiment, 160 persons have participated. The levels of the professional awareness of the correctional pedagogues have been provided with the indicators presented above.

The experiment on manifesting the levels of the professional awareness of the correctional pedagogues have been conducted $t$ several stages.

At the first stage based on the analysis of the scientific sources the category the "professional awareness" of the correctional pedagogue has been viewed upon in the content of the five components: professional-gnosiological, professional-reflexive, professional=axiological, professional-motivational, professionalemotional. 
At the second stage on the basis of structuring the professional awareness, the business games and five original questionnaires have been used. In the experiment, the correctional pedagogues with a different experience of work ( $0-5$ years of work; $5-10$ years of work; $10-15$ years of work) have taken part. The given stage has been aimed at obtaining the results of evaluating their own professional awareness by the correctional pedagogues. The results of the study are represented in Table 2 .

Table 2.

\section{Levels of Professional Awareness of Correctional \\ Pedagogues (in Accordance with the Results of Evaluating the studied Components of Own Professional Awareness)}

(\% of the total number)

\begin{tabular}{|c|c|c|c|}
\hline $\begin{array}{c}\text { Levels of } \\
\text { professional } \\
\text { awareness }\end{array}$ & $\begin{array}{c}\text { Correctional } \\
\text { pedagogueswith } \\
\text { 0-5yearsof } \\
\text { working }\end{array}$ & $\begin{array}{c}\text { Correctional } \\
\text { pedagogues with } \\
\text { 5-10 years of } \\
\text { working }\end{array}$ & $\begin{array}{c}\text { Correctional } \\
\text { pedagogues with } \\
\text { 10-15yearsof } \\
\text { working }\end{array}$ \\
\hline High & 9,38 & 11,88 & 16,87 \\
\hline Sufficient & 21,25 & 25 & 28,8 \\
\hline Initial & 35,62 & 36,25 & 33,12 \\
\hline Insufficient & 33,75 & 26,87 & 21,21 \\
\hline
\end{tabular}

At the second level of the experimental study, the methods of evaluation by the administrator (supervising professor, manager, director), the analysis of the special documentation, monitoring the activities and solving professional tasks by those under study have been used. The results of the study are represented in Table 3. The comparative analysis of the data presented in Tables 2 and 3 shows the direct dependence of the levels of development of the professional awareness of the correctional pedagogues from their professional experience of work. The higher the professional 
experience of work, the higher the level of the professional awareness of the correctional pedagogues, respectively.

Table 3

Levels of Professional Awareness of Correctional Pedagogues (in Accordance with the Results of Evaluating Professional Awareness of Correctional Pedagogues by their Administrators)

(\% of the total number)

\begin{tabular}{|c|c|c|c|}
\hline $\begin{array}{c}\text { Levels of } \\
\text { professional } \\
\text { awareness }\end{array}$ & $\begin{array}{c}\text { Correctional } \\
\text { pedagogues with } \\
\text { 0-5 years of } \\
\text { working }\end{array}$ & $\begin{array}{c}\text { Correctional } \\
\text { pedagogueswith } \\
\text { 5-10yearsof } \\
\text { working }\end{array}$ & $\begin{array}{c}\text { Correctional } \\
\text { pedagogues with } \\
\text { 10-15yearsof } \\
\text { working }\end{array}$ \\
\hline High & 6,25 & 8,75 & 11,87 \\
\hline Sufficient & 15 & 18,75 & 23,12 \\
\hline Initial & 38,75 & 40 & 38,12 \\
\hline Insufficient & 40 & 32,5 & 26,89 \\
\hline
\end{tabular}

At the third stage, the comparative analysis of the results of the first and the second stages of the experiment has been conducted. There have been significant differences in the data on the levels of development of the components of the professional awareness in the correctional pedagogues received from them and their leadership. The indicators of the levels of development of professional awareness at the first stage appear significantly higher than those obtained at the second stage.

At the fourth stage, the relationships between the levels of the professional awareness and various factors of the development of the professional activities have been established, the recommendations have been developed and offered concerning the development of the components of the professional awareness that have the low manifestation level. 
The influential factors regarding the level of development of the professional awareness of the correctional pedagogues have appeared: the experience of their professional activities, working conditions, personal circumstances, awareness of the importance of the level of the professional awareness and its components in the professional development of the employee.

1.2. Ways of Development of Professional Awareness of Correctional Pedagogues. Based on the results of the study, the recommendations concerning the development of the components of the low manifestation level have been developed.

1. Broadening of the experience of professional activities. Experience is a determining factor in the development of professional awareness. The longer the professional experience of the correctional pedagogue, the more complex it is and the wider the range of his/her professional duties, the higher the level of the professional awareness of the individual.

2. Creating the optimal working conditions for the correctional pedagogue. The working conditions have a multiplier effect on the level of development of the professional awareness of the correctional pedagogue. This influence has an individual character. The working conditions include wages, professional environment, relationships in the pedagogical team, schedule of work, etc. The influence of the working conditions on the professional development of the correctional pedagogue depends directly on his/her personal circumstances mentioned above.

3. Adapting the personal circumstances in order to optimize the professional activities of the correctional pedagogue. The personal circumstances include the influence of the family, the material situation, personal qualities of the correctional pedagogue, his/her preferences and life priorities. It is the personal circumstances of the correctional pedagogues, together with the experience of his/her work, are of paramount importance in determining the factors of influence on the development of professional awareness. 
4. Disseminating the knowledge on the issues of the significance of the level of professional awareness and its components in the professional development of the correctional pedagogue. The need for this measure stems from the understanding that awareness of the problem, as a rule, allows finding an effective solution for it. In order to develop the professional awareness, it is necessary to realize its importance for the success and effectiveness of one's own professional activities, to know the ways and methods of such work, to be able to apply them correctly.

The results of the experimental study indicate the need to develop advanced technologies for optimizing the levels of development of the professional awareness of the correctional pedagogues.

Discussion. The obtained results of the experimental study confirm the data of the scientists, who indicate the dependence of the professional awareness on the professional development of the personality (Klimov, 2004; Santrock, 2004; Tomasello, 2008); on the essence and significance of the professional-personality and professional-pedagogical qualities (Hordieieva, 2014; Ksenzova, 2009; Satanovska, 2016); on the significance of the factors of the social environment in forming the professional awareness of the correctional pedagogue (M.S. Omelchenko, 2017).

However, the scientists have not sufficiently demonstrated the degree of significance of each of the factors influencing the development of the professional awareness of pedagogues. In addition, there are no data on the success of creating and applying the developmental technologies to raise the level of the professional awareness of the correctional pedagogues.

Conclusions. The results of this study allow making the following conclusions:

- the development of the main components of the professional awareness of the correctional pedagogues is mainly on the initial (average level), which has been proved both the data of evaluation of 
the studied professional activities and the results of conversations with their administrators;

- the results of the evaluation of their own professional awareness by the correctional pedagogues are much higher than those given by their administrators during the experiment;

- with the increase of the professional working experience, the level of professional awareness grows significantly;

- the level of development of the professional awareness of the correctional pedagogues depends on such factors as the experience of professional activities, working conditions, personal circumstances, awareness of the significance of the level of the professional awareness and its components in the professional development of the employee;

- there is a need to develop advanced technologies to optimize the development of professional awareness in the correctional pedagogues with different working experience.

\section{References}

Hordieieva K.S. (2014). Profesiini tsinnosti v systemi sotsialnopedahohichnoi roboty: psykholohichnyi aspect [Professional Values in the System of Social-Pedagogical Work: Psychological Aspect]. Humanizatsiia navchalno-vykhovnoho protsesu - Humanization of Learning-Educational Process. Sloviansk: DDPU. Vypusk XVIII. (Ch.1.) 182-188 [in Ukrainian].

Klimov, E.A. (2004). Psikhologiia professionalnogo samoopredeleniia [Psychology of Professional Self-Determination]. M.: Akademiia [in Russian].

Ksenzova, T.N. (2009). Formirovanie professionalnykh predstavlenii u studentov v obrazovatelnom prostranstve VUZa [Formation of Professional Ideas of Students in the Educational Space of the Higher Educational Establishment]. Vestnik Moskovskogo gosudarstvennogo oblastnogo universiteta. Seriia: Pedagogika - Herald of Moscow State Regional University. Series: Pedagogy. № 2. 51-60 [in Russian].

Omelchenko M.S. (2018). Psykholohichni aspekty stanovlennia profesiinoi svidomosti korektsiinoho pedahoha [Psychological aspects of 
formation of the correctional teacher's professional consciousness]. Naukovyi visnyk Khersonskoho derzhavnoho universytetu. Seriia Psykholohichni nauky. - Scientific Herald of Kherson State University. Series: Psychological Sciences, 1, Tom I, 143-147 [in Ukrainian].

Satanovska, L.A. (2016). Formuvannia tsinnostei ta tsinnisnykh profesiinykh oriientatsii studentskoi molodi u vyshchykh navchalnykh zakladakh Ukrainy [Formation of Values and Valuable Professional Orientations of Students' Youth in the Higher Educational Establishments of Ukraine]. Visnyk Kyivskoho natsionalnoho universytetu imeni Tarasa Shevchenka. Pedahohika - Herald of Taras Shevchenko Kyiv National University. Pedagogy. (Vol. 1.) 58-65 [in Ukrainian].

Slobodchikov, V.I. (2013). Psikhologiia cheloveka: vvedenie v psikhologiiu subieektivnosti [Psychology of Subjectivity]. M.: Izd-vo PSTGU [in Russian].

Santrock J. W. (2004) Educational psychology. Boston [etc.] : McGraw-Hill [in Englisch].

Tomasello M. (2008) Origins of Human Communication. MIT Press [in Englisch]. URL https://www.livelib.ru/author/325364-majkltomasello

Оригінальний рукопис отриманий 15 травня 2019 року

Стаття прийнята до друку 28 травня 2019 року 